\title{
Saline water on the leaf mineral composition of noni under organic fertilization
}

\author{
Maria C. M. R. de Souza ${ }^{1}$, Ademir S. Menezes ${ }^{2}$, Rafael S. da Costa ${ }^{3}$, Claudivan F. de Lacerda ${ }^{4}$, \\ Aiala V. Amorim ${ }^{5}$ \& Antônia I. S. Ximenes ${ }^{1}$
}

${ }^{1}$ Instituto Federal do Ceará. Sobral, CE, Brasil. E-mail: profmariacristinasouza@gmail.com - ORCID: 0000-0001-9094-6585; isabelaximenes52@gmail.com - ORCID: 00000003-1749-4441

${ }^{2}$ Faculdade Ieducare/Departamento de Engenharia Agrícola e Ambiental. Tianguá, CE, Brasil. E-mail: amenezzes@gmail.com - ORCID: 0000-0002-7780-3712

${ }^{3}$ Universidade Federal do Ceará/Departamento de Fitotecnia. Fortaleza, CE, Brasil. E-mail: rafaelsantiagodacosta@yahoo.com.br - ORCID: 0000-0002-3158-2117

${ }^{4}$ Universidade Federal do Ceará/Departamento de Engenharia Agrícola. Fortaleza, CE, Brasil, E-mail: claudivan_@hotmail.com (Corresponding author) - ORCID: 00000002-5324-8195

${ }^{5}$ Universidade da Integração Internacional da Lusofonia Afro-Brasileira/Instituto de Desenvolvimento Rural. Redenção, CE, Brasil. E-mail: aialaamorim@unilab.edu.br ORCID: 0000-0003-4222-3459

\begin{abstract}
Salinity is one of the main agricultural problems faced, and may negatively influence plant development. However, studies have shown that in protected environments and under the application of organic fertilizers, deleterious effects are mitigated. In this context, the objective of this study was to evaluate the effects of irrigation water salinity on mineral nutrition in noni plants grown in two environments and bovine manure application. The statistical design was a randomized block design arranged in split-split plot scheme, with five repetitions. The plots consisted of the cultivation environments (greenhouse and open field), the subplots formed by salinity levels of irrigation water (ECw: $0.3,1.5,3.0,4.5$ and $6.0 \mathrm{dS} \mathrm{m}^{-1}$ ), and the subsubplots were represented by the absence and presence of organic matter, with experimental unit consisting of three pots totaling 300 pots. The nitrogen, potassium, calcium, magnesium, sodium and chloride concentrations were determined in plant leaves. It was verified that the foliar concentrations of $\mathrm{Ca}^{2+}, \mathrm{Mg}^{2+}, \mathrm{Na}^{+}$and $\mathrm{Cl}^{-}$and the ratio $\mathrm{Na} / \mathrm{K}$ was increased with increasing salinity of the irrigation water, being the largest increments observed in the open field. Organic matter is not much relevant in attenuating the deleterious effects of irrigation water on the concentration of leaf nutrient in noni plants. The maintenance of lower values of $\mathrm{Na} / \mathrm{K}$ ratio in the treatment with organic matter is a positive factor that can attenuate the effects of salt stress on cell metabolism.
\end{abstract}

Key words: Morinda citrifolia, bovine manure, salt stress, mineral nutrition

\section{Água salina na composição mineral foliar de noni sob adubação orgânica}

RESUMO: A salinidade é um dos principais problemas agrícolas enfrentados, podendo influenciar negativamente o desenvolvimento vegetal. Porém, estudos têm demonstrado que em ambientes protegidos e sob aplicação de adubos orgânicos, os efeitos deletérios são amenizados. Nesse contexto, objetivou-se avaliar os efeitos da salinidade da água de irrigação sobre a nutrição mineral em plantas de noni, cultivadas em dois ambientes sob adubação com esterco bovino. O delineamento experimental foi em blocos ao acaso, disposto no esquema de parcelas subsubdivididas com cinco repetições. As parcelas foram constituídas pelos ambientes de cultivo (céu aberto e telado), as subparcelas pelas salinidades da água de irrigação $\left(0,3 ; 1,5 ; 3,0 ; 4,5\right.$ e $\left.6,0 \mathrm{dS} \mathrm{m} \mathrm{m}^{-1}\right)$ e as subsubparcelas pela ausência e presença de matéria orgânica, com a unidade experimental consistindo de três vasos, totalizando 300 vasos. Foram determinados as concentrações foliares de nitrogênio, potássio, cálcio, magnésio, sódio e cloreto. Verificou-se que os teores foliares de $\mathrm{Ca}^{2+}, \mathrm{Mg}^{2+}, \mathrm{Na}^{+}$e $\mathrm{Cl}^{-}$e a razão $\mathrm{Na} / \mathrm{K}$ aumentaram com o aumento da salinidade da água de irrigação, sendo os maiores incrementos observados no ambiente a céu aberto. A matéria orgânica não é relevante o suficiente para atenuar os efeitos deletérios da água de irrigação na concentração de nutrientes foliares em plantas de noni. A manutenção de menores valores da razão $\mathrm{Na} / \mathrm{K}$ no tratamento com matéria orgânica é um fator positivo que pode atenuar os efeitos do estresse salino no metabolismo celular.

Palavras-chave: Morinda citrifolia, esterco bovino, estresse salino, nutrição mineral 


\section{INTRODUCTION}

Noni (Morinda citrifolia L.) is a plant belonging to the Rubiaceae family, with extensive medicinal use, because it has great antioxidant, dyslipidemic, hypotensive, healing, antimicrobial and analgesic potential (Krishnaiah et al., 2013; Mompié et al., 2014; Pandy et al., 2014). Noni cultivation is greatly favored in tropical climate environments, because the plant is able to adapt to the most diverse situations of climate, soil and abiotic stresses (Singh, 2012; Souto et al., 2015).

Salinity is one of the abiotic stresses that most limit plant development, because nutrient absorption rate is reduced in saline environment, negatively influencing the mineral nutrition and yield of plants worldwide, including noni (Freire et al., 2011; Lima et al., 2014; Souza et al., 2017). Thus, the use of strategies aimed at mitigating salt stress in plants is a viable alternative to favor full plant development (Silva et al., 2013).

One of these strategies is the use of organic compounds such as organic matter, which can reduce the exchangeable sodium percentage (ESP), increase water retention in the substrate, promote greater aggregation of soil particles and act as a source of nutrients, such as calcium, magnesium, nitrogen and phosphorus (Oliveira et al., 2014). Another important strategy for tropical regions is the cultivation in protected environments (Sousa et al., 2012b; Taiz et al., 2017).

With regard to the cultivation environment, it is known that it has great importance for plant development, since climatic factors such as temperature, luminosity and water availability directly interfere with the absorption of nutrients by plants and, consequently, with their physiological and production responses (Silva et al., 2013; Taiz et al., 2017).

Therefore, this study aimed to evaluate the influence of saline water irrigation on the leaf concentrations of nitrogen, potassium, calcium, magnesium, sodium and chloride of noni plants cultivated in substrate with and without organic matter in two environments.

\section{Material ANd Methods}

The experiment lasted a total of approximately seven months, from the preparation of noni seedlings in May 2011 until the harvesting in December 2011, and was carried out in a seedling production garden of the municipality of Sobral, $\mathrm{CE}$, Brazil, located at geographic coordinates of $3^{\circ} 41^{\prime} 10^{\prime \prime} \mathrm{S}$ and $40^{\circ} 20^{\prime} 59^{\prime \prime} \mathrm{W}$, with an altitude of $70 \mathrm{~m}$.

According to Köppen's classification, this region has a BSw'h' climate, because it has a typically hot tropical climate, with summer rains (Alvares et al., 2013). Along the experimental period, the average rainfall was $39.52 \mathrm{~mm}$ and the average maximum and minimum temperatures were 36.2 and $21.6^{\circ} \mathrm{C}$, for the environment in open field and 34.4 and $20.4^{\circ} \mathrm{C}$, for the shaded environment.

The experiment was conducted in a randomized block design, in split-split plots, with five repetitions. Plots consisted of the cultivation environments (open field and under 50\% shade net), subplots consisted of levels of irrigation water salinity - ECw: 0.3, 1.5, 3.0, 4.5 and $6.0 \mathrm{dS} \mathrm{m}^{-1}$ ) and the sub-subplots were represented by the absence and presence of organic matter, with three plants per plot, totaling 300 experimental units.

Noni seedlings were produced from seeds obtained in a commercial plantation located in the municipality of Trairi, $\mathrm{CE}$, Brazil. The seeds were removed from the fruit, washed in running water and dried in the shade on absorbent paper for $48 \mathrm{~h}$. Then, they were sown in cell-type trays containing substrate formulated from the mixture of $50 \%$ washed sand + $50 \%$ aged bovine manure.

At 60 days after sowing (DAS), the most vigorous seedlings were selected, transplanted to $2-\mathrm{L}$ polyethylene bags $(15 \mathrm{~cm}$ wide x $28 \mathrm{~cm}$ long), containing a mixture of bovine manure (aged) and soil, in a 1:1 proportion. For each $20 \mathrm{~L}$ of this mixture, $500 \mathrm{~g}$ of the 4:14:8 (NPK) formulation was applied based on soil analysis. The seedlings were irrigated daily using water with electrical conductivity of $0.3 \mathrm{dS} \mathrm{m}^{-1}$ and, when they had four to six pairs of true leaves, at $80 \mathrm{DAS}$, they were planted in 20 -L pots ( $50 \mathrm{~cm}$ wide $\mathrm{x} 90 \mathrm{~cm}$ high) for the experiment.

The pots were filled with $10 \mathrm{~L}$ of sandy soil in the lower half and a mixture of $5 \mathrm{~L}$ of sandy soil $+5 \mathrm{~L}$ of bovine manure in the upper half. In relation the pots filled only with soil, was used an amount of $20 \mathrm{~L}$. A 2-cm-thick layer of crushed stone was placed at the bottom to facilitate drainage. The physical and chemical characteristics of the two substrates were analyzed and the results are presented in Table 1.

Based on the results of the substrate analysis, plants were fertilized to correct any deficiencies. Each pot received, as basal fertilization, $0.5 \mathrm{~g}$ of urea, $1.0 \mathrm{~g}$ of single superphosphate and $0.5 \mathrm{~g}$ of potassium chloride, and, as topdressing, $0.5 \mathrm{~g}$ of urea and $0.5 \mathrm{~g}$ of potassium chloride, at 30, 45 and 60 days after basal fertilization. At the $2^{\text {nd }}$ topdressing application, 45 days after basal fertilization, $1 \mathrm{~g} \mathrm{plant}^{-1}$ of micronutrient (FTE Br-12) was applied. At 60 days after basal fertilization, foliar fertilization was performed with $2 \mathrm{mM}$ of magnesium sulfate and $1 \mathrm{mM}$ of calcium sulfate only in plants of the control treatment.

To achieve the desired levels of irrigation water electrical conductivity (ECw), different quantities of $\mathrm{NaCl}, \mathrm{CaCl}_{2} \cdot 2 \mathrm{H}_{2} \mathrm{O}$ and $\mathrm{MgCl}_{2} \cdot 6 \mathrm{H}_{2} \mathrm{O}$ salts, in a 7:2:1 equivalent proportion, were added to the water of lowest salinity, according to the relationship between ECw and the concentration $\left(\mathrm{mmol}_{\mathrm{c}} \mathrm{L}^{-1}\right.$ $=\mathrm{EC} \times 10$ ), using the methodology of Rhoades et al. (2000). Irrigation was performed on alternating days and the volume of solution applied to the plants was in accordance with the drainage lysimeter principle, keeping the soil at field capacity

Table 1. Physical and chemical attributes of the substrates used in the experiment

\begin{tabular}{|c|c|c|}
\hline Characteristics & $\begin{array}{l}\text { Treatment without } \\
\text { organic matter }\end{array}$ & $\begin{array}{l}\text { Treatment with } \\
\text { organic matter }\end{array}$ \\
\hline Textural classification & Sand & Sand \\
\hline \multicolumn{3}{|l|}{ Attributes } \\
\hline $\mathrm{pH}$ in water & 6.20 & 7.00 \\
\hline $\mathrm{EC}\left(\mathrm{dS} \mathrm{m}^{-1}\right)$ & 0.14 & 1.40 \\
\hline$P\left(\mathrm{mg} \mathrm{dm}^{-3}\right)$ & 74.00 & 669.00 \\
\hline $\mathrm{Ca}^{+2}\left(\mathrm{mmol}_{\mathrm{c}} \mathrm{dm}^{-3}\right)$ & 42.00 & 40.00 \\
\hline $\mathrm{Mg}^{+2}\left(\mathrm{mmol}_{\mathrm{c}} \mathrm{dm}^{-3}\right)$ & 6.00 & 37.00 \\
\hline $\mathrm{Na}^{+}\left(\mathrm{mmol}_{\mathrm{c}} \mathrm{dm}^{-3}\right)$ & 1.20 & 16.17 \\
\hline $\mathrm{K}^{+}\left(\mathrm{mmol}_{\mathrm{c}} \mathrm{dm}^{-3}\right)$ & 1.47 & 24.07 \\
\hline $\mathrm{H}^{+}+\mathrm{Al}^{3+}\left(\mathrm{mmol}_{\mathrm{c}} \mathrm{dm}^{-3}\right)$ & 23.93 & 28.88 \\
\hline Organic matter $\left(\mathrm{g} \mathrm{kg}^{-1}\right)$ & 3.72 & 24.72 \\
\hline
\end{tabular}


and adding a leaching fraction of 0.20 in order to favor the leaching of salts. Water application was made in a localized manner, so as to avoid direct contact with the leaves.

All leaves were collected at 110 days after transplanting (DAT), placed in properly identified paper bags and dried in an air circulation oven at $65^{\circ} \mathrm{C}$, until constant weight. The samples were crushed and then taken to the laboratory to determine the leaf concentrations of nitrogen $(\mathrm{N})$, potassium $(\mathrm{K})$, calcium $(\mathrm{Ca})$, magnesium $(\mathrm{Mg})$, sodium $(\mathrm{Na})$ and chloride (Cl), following the methodologies proposed by Cataldo et al. (1975), Malavolta et al. (1997) and Silva (2009).

The data were subjected to analysis of variance at $\mathrm{p} \leq 0.05$ by $\mathrm{F}$ test. The means of environments and of bovine manure were compared by Tukey test $(\mathrm{p} \leq 0.05)$, while irrigation water salinity were subjected to polynomial regression ( $\mathrm{p} \leq 0.05$ ). Data analysis was carried out using the statistical program Assistat 7.7 Beta (Silva \& Azevedo, 2016).

\section{RESUlts AND Discussion}

According to the values of mean square, the salinity $x$ environment interaction interfered with the mineral composition of noni leaves, except for chloride (Table 2). The environment $x$ organic matter interaction influenced the concentrations of nitrogen, calcium, magnesium and chloride. The leaf concentrations of magnesium and sodium and the sodium/potassium ratio responded to the interaction between water salinity and organic matter. There was no significant effect of the environment $\times$ salinity $\times$ organic matter interaction on leaf nutrient concentrations of noni plants.

The leaf nitrogen concentrations of noni plants cultivated in the open field increased as the water electrical conductivity increased, with increments of $0.999 \mathrm{~g} \mathrm{~kg}^{-1}$ due to the increase of ECw (Figure 1A). In general, when cultivated in a shaded environment, noni plants showed higher $\mathrm{N}$ concentrations than those cultivated in the open field.

Table 2. Summary of the analysis of variance, for the concentrations of nitrogen, potassium, calcium, magnesium, sodium, chloride and the $\mathrm{Na} / \mathrm{K}$ ratio in leaves of noni plants in response to the cultivation environment (Env), irrigation water salinity $(\mathrm{ECw})$ and organic matter $(\mathrm{OM})$ in the substrate

\begin{tabular}{|c|c|c|c|c|c|c|c|c|}
\hline \multirow{2}{*}{$\begin{array}{l}\text { Sources } \\
\text { of variation }\end{array}$} & \multirow{2}{*}{ DF } & \multicolumn{7}{|c|}{ Mean square } \\
\hline & & $\overline{\mathbf{N}}$ & $\bar{K}$ & $\mathrm{Ca}$ & $\mathrm{Mg}$ & $\mathrm{Na}$ & $\overline{\mathbf{C I}}$ & $\mathrm{Na} / \mathrm{K}$ \\
\hline Block & 4 & $3.69^{\text {ns }}$ & $29.49^{\text {ns }}$ & $92.91 *$ & $1.84^{\mathrm{ns}}$ & $14.12^{\text {ns }}$ & $0.37^{\text {ns }}$ & $14.19^{\text {ns }}$ \\
\hline Env (a) & 1 & $475.68^{\star}$ & $967.71^{\star \star}$ & $249.08^{*}$ & $62.43^{* *}$ & $338.25^{\star *}$ & $35.51^{\star *}$ & $341.16^{\star \star}$ \\
\hline Residue (a) & 4 & 33.29 & 12.18 & 10.64 & 0.65 & 10.11 & 0.27 & 9.79 \\
\hline $\mathrm{ECw}(\mathrm{b})$ & 4 & $25.33^{* *}$ & $193.65^{\star *}$ & $28.14^{\star *}$ & $2.12^{\star \star}$ & $214.44^{* *}$ & $10.98^{* *}$ & $213.32^{* \star}$ \\
\hline Env $\times E C w$ & 4 & $42.85^{\star \star}$ & $45.05^{\star}$ & $15.00^{* *}$ & $1.57^{\star \star}$ & $4.31^{\star \star}$ & $0.67^{\text {ns }}$ & $21.58 * \star$ \\
\hline Residue (b) & 32 & 4.41 & 11.79 & 5.48 & 0.32 & 4.96 & 0.36 & 4.95 \\
\hline $\mathrm{OM}(\mathrm{c})$ & 1 & $430.06^{\star *}$ & $620.91^{\star *}$ & $3.77^{\mathrm{ns}}$ & $3.51^{\star \star}$ & $116.61^{* *}$ & $2.88^{\star}$ & $116.71^{\star \star}$ \\
\hline Env $\times 0 \mathrm{M}$ & 1 & 132.81 ** & $5.96^{\mathrm{ns}}$ & $58.95^{\star *}$ & $1.52^{\star}$ & $1.72^{\mathrm{ns}}$ & $9.04^{* *}$ & $1.73^{\mathrm{ns}}$ \\
\hline $\mathrm{ECW} \times \mathrm{OM}$ & 4 & $3.30^{\text {ns }}$ & $3.29^{\text {ns }}$ & $0.61^{\mathrm{ns}}$ & $4.74^{\star \star}$ & $22.18^{\star *}$ & $0.32^{\mathrm{ns}}$ & 22.60 ** \\
\hline $\mathrm{Env} \times \mathrm{ECw} \times \mathrm{OM}$ & 4 & $8.71^{\text {ns }}$ & $3.59^{\text {ns }}$ & $10.17^{\mathrm{ns}}$ & $0.57^{\text {ns }}$ & $5.93^{\text {ns }}$ & $0.36^{\mathrm{ns}}$ & $5.44^{\mathrm{ns}}$ \\
\hline Residue (c) & 40 & 7.89 & 9.04 & 7.6 & 0.26 & 5.52 & 0.67 & 5.63 \\
\hline CV (\%) (a) & & 26.39 & 16.96 & 12.25 & 13.69 & 41.94 & 13.18 & 41.23 \\
\hline CV (\%) (b) & & 9.6 & 16.68 & 8.79 & 9.38 & 29.4 & 15.32 & 29.33 \\
\hline CV (\%) (c) & & 12.84 & 14.6 & 10.35 & 8.76 & 31 & 20.8 & 31.29 \\
\hline
\end{tabular}

${ }^{* *},{ }^{*}$ and ${ }^{n s}$ Significant at $\mathrm{p} \leq 0.01$, at $\mathrm{p} \leq 0.05$ and not significant by $\mathrm{F}$ test, respectively; CV - Coefficient of variation; DF - Degrees of freedom

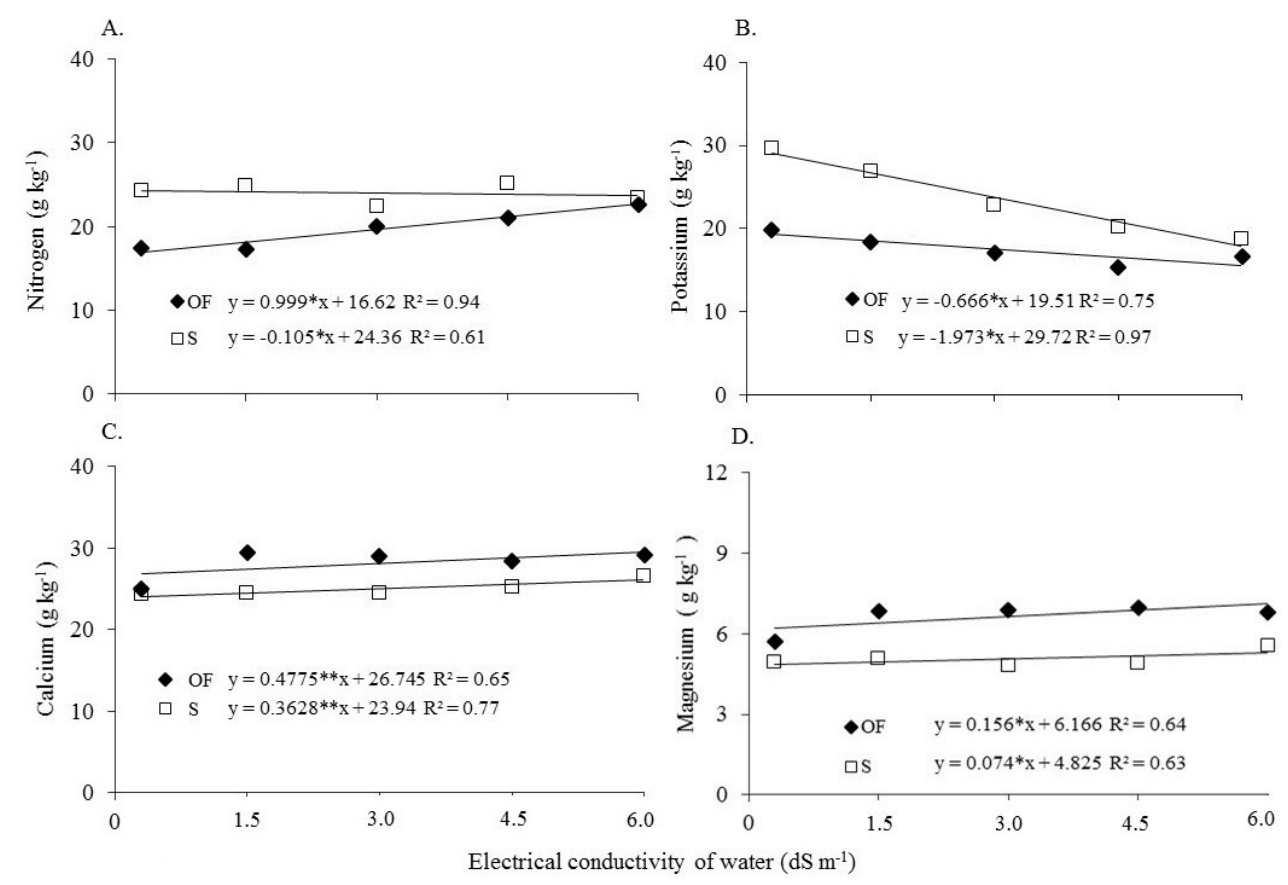

*, ** - Significant at $\mathrm{p} \leq 0.05$ and $\mathrm{p} 0.01$ by F test, respectively

Figure 1. Leaf concentrations of nitrogen (A), potassium (B), calcium (C) and magnesium (D) in leaves of noni plants irrigated with saline water and cultivated in open field (OF) and shaded environment (S) 
Different results were reported by Lucena et al. (2012), who evaluated the effect of salt stress on nutrient absorption in mango cultivars grown in greenhouse and observed that the increase of salinity caused significant reduction in the $\mathrm{N}$ concentrations of the cultivars evaluated. Similarly, salinity reduced the $\mathrm{N}$ concentrations in the leaves and roots of Gliricidia sepium grown under shaded conditions, compromising the initial growth of plants in nutrient solution containing $\mathrm{NaCl}$ (Farias et al., 2009).

In relation to the potassium concentrations, the increase of salt concentrations in the irrigation water reduced leaf $\mathrm{K}$ concentrations, especially in plants cultivated in shaded environment (Figure 1B). When the lowest ECw $\left(0.3 \mathrm{dS} \mathrm{m}^{-1}\right)$ was compared to the highest $\mathrm{ECw}\left(6.0 \mathrm{dS} \mathrm{m}^{-1}\right)$, there were reductions of 19.65 and $38.59 \%$ in the $\mathrm{K}$ concentrations of plants in the open field and shaded environment, respectively. This occurred due to the increase of $\mathrm{Na}$ concentrations caused by saline water irrigation, because $\mathrm{Na}$ competes with $\mathrm{K}$ for the absorption sites in the plasmatic membrane, reducing the amount of the element in the leaf tissue (Taiz et al., 2017).

Leaf Ca concentrations in noni leaves positively responded to the increasing salinity of irrigation water. In the open field environment, the increment was $10.15 \%$ while in the shaded environment the increase was $8.61 \%$ (Figure 1C). This increase was higher in plants grown in the open field environment with a linear increment of $0.4755 \mathrm{~g} \mathrm{~kg}^{-1}$, while in the shaded environment it was $0.3628 \mathrm{~g} \mathrm{~kg}^{-1}$, both considering unit increase of electrical conductivity of water.

The increase in Ca concentrations in the leaves can be justified by the presence of this nutrient in the composition of the water used, since the concentration of this element increases with the increment in water salinity. Similar results were found by Sousa et al. (2012a) in Jatropha curcas L. irrigated using saline water with equivalent proportion of 7:2:1 for the cations $\mathrm{Na}^{+}, \mathrm{Ca}^{2+}$ and $\mathrm{Mg}^{2+}$, respectively. These authors observed that $\mathrm{Ca}$ concentrations in the leaves increased linearly with increasing water salinity.

Irrigation water salinity caused linear increments in the leaf $\mathrm{Mg}$ concentrations of noni plants in both cultivation environments (Figure 1D). The unit increase in irrigation water salinity resulted in linear increments of $0.156 \mathrm{~g} \mathrm{~kg}^{-1}$ in plants grown in the open field and $0.074 \mathrm{~g} \mathrm{~kg}^{-1}$ in plants grown in shaded environment. Noni plants grown in the open field accumulated about $20 \%$ more $\mathrm{Mg}$ than those cultivated in the shaded environment, which possibly occurred due to the higher photosynthetic efficiency of the plants in this environment, since plants cultivated in open field usually have higher photosynthetic rate.

The increase of $\mathrm{Mg}$ concentrations in the leaves results from the higher concentration of this cation in the chemical composition of irrigation water in the treatments with higher electrical conductivity. In addition, Sousa et al. (2012a), working with Jatropha curcas L. subjected to irrigation with saline water composed of the cations $\mathrm{Na}^{+}, \mathrm{Ca}^{2+}$ and $\mathrm{Mg}^{2+}$, in equivalent proportion of 7:2:1, observed the leaf $\mathrm{Mg}$ concentrations increased as a function of irrigation water salinity.

With regard to the $\mathrm{Na}$ concentrations in the leaves, there were increments as a function of the increase in irrigation water salinity, with higher intensity in plants cultivated in open field (Figure 2A), with an increment rate of $1.661 \mathrm{~g} \mathrm{~kg}^{-1}$ per unit increase in salinity.

It was observed that the chloride concentrations in noni leaves increased with the increment in irrigation water salinity up to 4.18 and $4.87 \mathrm{dS} \mathrm{m}^{-1}$, respectively, in the shaded environment and open field, respectively, reaching maximum estimated values of 4.3 and $3.17 \mathrm{~g} \mathrm{~kg}^{-1}$ of $\mathrm{Cl}$ in the leaves (Figure 2B). In a comparison of the cultivation environments, it can be observed that, when cultivated under shade net, plants accumulated more chloride, which can be justified by the lower efficiency in the physiological apparatus since the accumulation of toxic ions such as sodium and chloride can increase chloroplast degradation (Taiz et al., 2017).

The $\mathrm{Na} / \mathrm{K}$ ratio increased linearly with increased irrigation water salinity in both environments (Figure 2C). In general, when cultivated in the open field, plants had higher values of $\mathrm{Na} / \mathrm{K}$ ratio. Increments of 0.094 and 0.0513 with per unit increase in irrigation water electrical conductivity were observed for plants cultivated in open field and shaded environment, respectively.

For $\mathrm{Na}$ concentrations, as well as for $\mathrm{Na} / \mathrm{K}$ ratio, plants showed increments with the increase in irrigation water salinity, which was already expected, due to the increase in $\mathrm{Na}$ absorption and reduction in $\mathrm{K}$ absorption. Likewise, the $\mathrm{Na} / \mathrm{K}$ ratio in the leaves of castor bean (Ricinus communis) increased
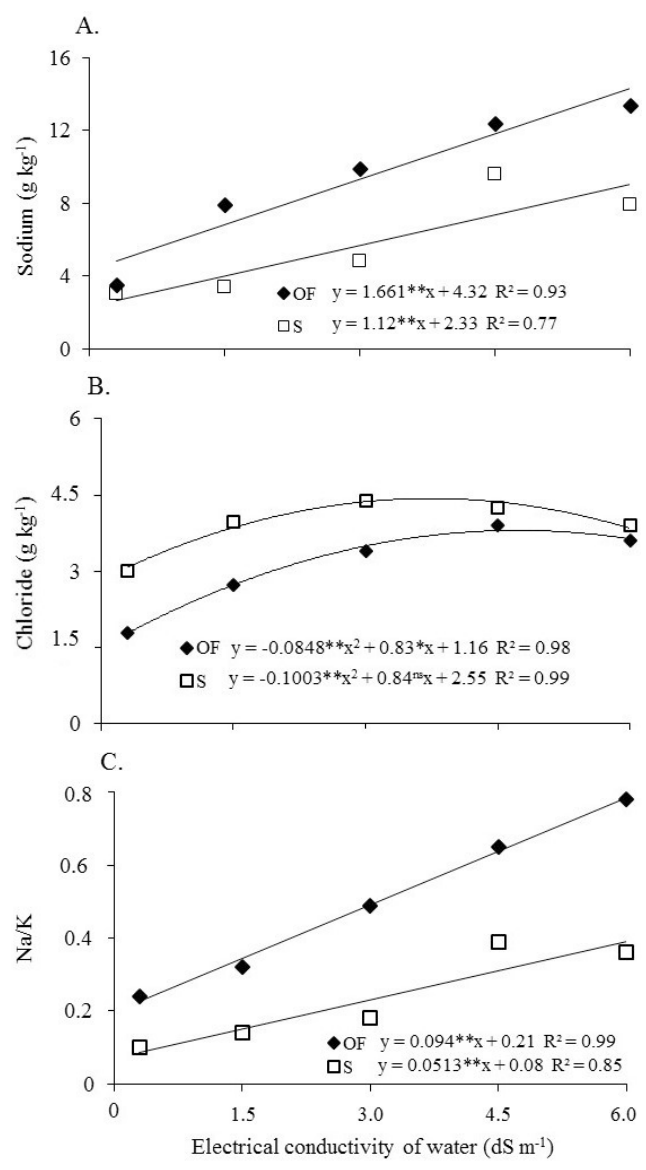

*, ** - Significant at $\mathrm{p} \leq 0.05$ and $\mathrm{p} \leq 0.01$ by $\mathrm{F}$ test, respectively

Figure 2. Leaf concentrations of sodium (A), chloride (B) and $\mathrm{Na} / \mathrm{K}$ ratio $(\mathrm{C})$ in leaves of noni plants irrigated with saline water and cultivated in open field (OF) and shaded environment $(S)$ 
with the increment of salts in the water used for irrigation up to the electrical conductivity of $3.9 \mathrm{dS} \mathrm{m}^{-1}$. However, in the case of castor bean, the increase in $\mathrm{Na} / \mathrm{K}$ ratio was due to the increase in the leaf $\mathrm{Na}$ concentration, and there was no reduction in $\mathrm{K}$ concentration (Lima et al., 2015).

$\mathrm{Na} / \mathrm{K}$ ratios equal to or lower than 0.6 are considered optimal for metabolic efficiency in non-halophytes, and this variable has been considered as criterion for the selection of genotypes that are more tolerant to salinity (Alves et al., 2008; Santos et al., 2016). Noni plants cultivated in shaded environment showed better responses, with $\mathrm{Na} / \mathrm{K}$ ratios much lower than 0.6. On the other hand, at water salinity levels of 4.5 and $6.0 \mathrm{dS} \mathrm{m}^{-1}$, plants cultivated in the open field showed $\mathrm{Na} / \mathrm{K}$ ratios higher than 0.6 , which may be indicative of metabolic damage caused to cells of plants grown in this environment (Souto et al., 2015).

The application of organic matter increased leaf $\mathrm{N}$ concentrations in the shaded environment (Table 3).

According to Souza et al. (2014), organic matter supply can contribute to the growth of noni plants, as well as to the increase of leaf $\mathrm{N}$ concentrations. Results similar to those found in the present study were reported by Silva et al. (2014) and Souto et al. (2018), who worked with bovine manure and K in the mineral composition of noni plants (Morinda citrifolia) and observed that the leaf $\mathrm{N}$ concentrations increased with the addition of bovine manure.

The largest concentration of $\mathrm{N}$ observed in the shaded environment in the presence of OM may be related to the greater control of edaphoclimatic conditions, such as temperature, air humidity, radiation and wind, which interfere with water availability and nutrient absorption (Galati et al., 2013).

The leaf concentrations of Ca did not differ between the environments in the treatments without organic matter (Table 3). For Mg, the highest leaf concentrations were found in plants grown in substrate with organic matter and in open field, followed by the same environment and without this organic matter (Table 3), demonstrating that the shaded environment hampers $\mathrm{Mg}$ accumulation in noni leaves.

This occurred because the manure supplies larger amounts of N, compared to plants without bovine manure. Since N and

Table 3. Leaf concentrations of nitrogen, calcium, magnesium and chloride in leaves of noni plants cultivated in open field and shaded environment and in substrate without and with bovine manure

\begin{tabular}{lcc}
\hline Environment & Without organic matter & With organic matter \\
& \multicolumn{2}{c}{ Nitrogen $\left(\mathrm{g} \mathrm{kg}^{-1}\right)$} \\
Open field & $18.76 \mathrm{aA}$ & $20.60 \mathrm{aA}$ \\
Shaded & $20.82 \mathrm{aB}$ & $27.27 \mathrm{aA}$ \\
\hline \multicolumn{3}{c}{ Calcium $\left(\mathrm{g} \mathrm{kg}^{-1}\right)$} \\
Open field & $27.60 \mathrm{aA}$ & $28.80 \mathrm{aA}$ \\
Shaded & $26.00 \mathrm{aA}$ & $24.10 \mathrm{bB}$ \\
\hline \multicolumn{3}{c}{ Magnesium $\left(\mathrm{g} \mathrm{kg}^{-1}\right)$} \\
Open field & $6.30 \mathrm{aB}$ & $6.90 \mathrm{aA}$ \\
Shaded & $5.30 \mathrm{bA}$ & $5.30 \mathrm{bA}$ \\
\hline \multicolumn{3}{r}{ Chloride $\left(\mathrm{g} \mathrm{kg}^{-1}\right)$} \\
Open field & $3.20 \mathrm{bA}$ & $3.50 \mathrm{bA}$ \\
Shaded & $5.00 \mathrm{aA}$ & $4.10 \mathrm{aB}$ \\
\hline
\end{tabular}

Means followed by the same lowercase letters in the columns and uppercase letters in the rows did not differ at $\mathrm{p} \leq 0.01$ and $\mathrm{p} \leq 0.05$ by Tukey test
$\mathrm{Mg}$ are directly related to chlorophyll synthesis and because plants are under direct light, this possibly helped promote better use of the physiological apparatus and consequently led to higher $\mathrm{N}$ and $\mathrm{Mg}$ concentrations in plants that received manure.

The highest concentrations of chloride in noni leaves were observed in the shaded environment and without organic matter in the substrate, being 18, 36 and 30\% higher than those found in the shaded environment with organic matter in the substrate, the open field environment without organic matter and the open field environment with organic matter, respectively (Table 3 ). However, it is not clear that organic matter is an attenuator of salt stress, because the reduction in $\mathrm{Cl}$ concentration by the addition of bovine manure occurred only in the shaded environment. For this case, there may be a relationship between higher nutrient availability and reduction in chloride accumulation.

In relation to the interactive effect of the factors salinity $x$ organic matter on noni leaves, it was observed that, in the presence of organic matter, the leaf $\mathrm{Mg}$ concentrations decrease by $8.71 \%$ between the lowest ECw $\left(0.3 \mathrm{dS} \mathrm{m}^{-1}\right)$ and the highest $\mathrm{ECw}\left(6.0 \mathrm{dS} \mathrm{m}^{-1}\right)$, while plants without the fertilizer showed an increase of $39.28 \%$ (Figure $3 \mathrm{~A}$ ). The increase in leaf $\mathrm{Mg}$ concentrations observed in plants grown in substrate without bovine manure is due to the accumulation of this ion caused by the greater availability with the increase in irrigation water salinity.
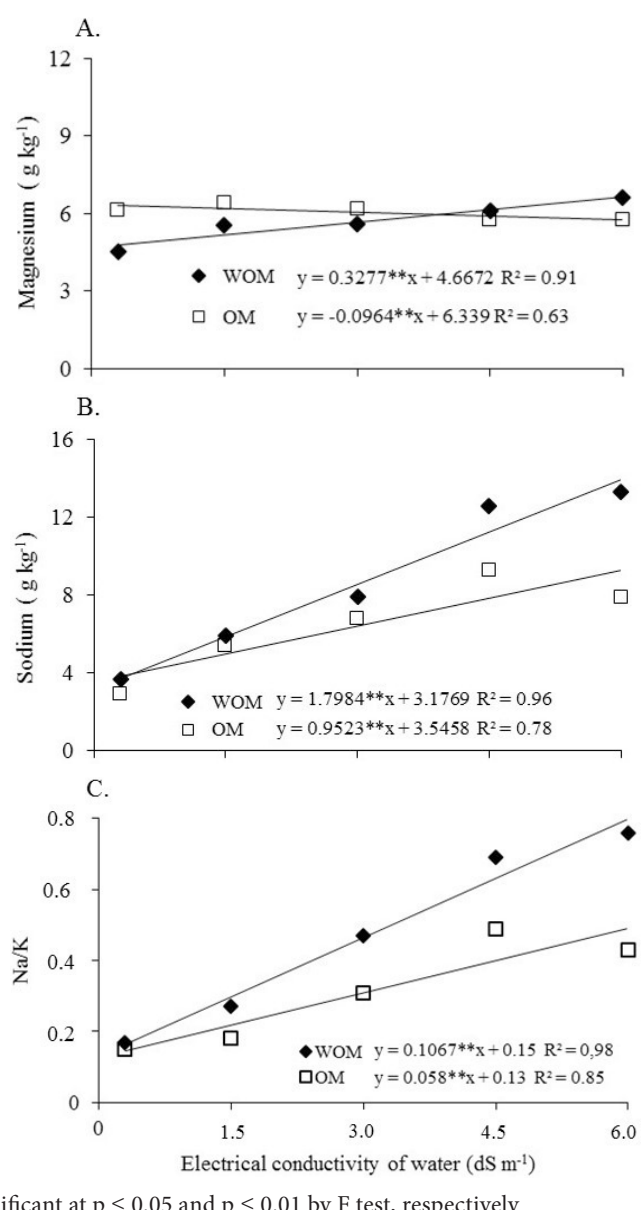

* ** - Significant at $\mathrm{p} \leq 0.05$ and $\mathrm{p} \leq 0.01$ by F test, respectively

Figure 3. Leaf concentrations of magnesium (A), sodium (B) and $\mathrm{Na} / \mathrm{K}$ ratio $(\mathrm{C})$ in leaves of noni plants cultivated with $(\mathrm{OM})$ and without (WOM) bovine manure in the substrate and irrigated with saline water 
The increment in irrigation water salinity increased $\mathrm{Na}$ concentration in noni leaves and with higher intensity in the substrate without organic matter (Figure 3B). In plants that did not receive organic matter, leaf $\mathrm{Na}$ concentrations increased linearly by $1.7984 \mathrm{~g} \mathrm{~kg}^{-1}$ per unit increment in the electrical conductivity, whereas in the treatment with the organic matter this increase was $0.9523 \mathrm{~g} \mathrm{~kg}^{-1}$. Between the lowest ECw $\left(0.3 \mathrm{dS} \mathrm{m}^{-1}\right)$ and the highest ECw $\left(6.0 \mathrm{dS} \mathrm{m}^{-1}\right)$, leaf $\mathrm{Na}$ concentrations increased by 3.8 times in plants that did not receive bovine manure and by 2.4 times in plants that received bovine manure.

For the $\mathrm{Na} / \mathrm{K}$ ratio, it was observed that plants cultivated both in the presence and in the absence of organic matter showed linear increments of 0.1167 and 0.058 , respectively (Figure 3C), per unit increase in irrigation water conductivity electrical. Plants cultivated without organic matter showed higher values than plants cultivated in the presence of organic matter at all levels of irrigation water salinity. This possibly occurred because of their response to $\mathrm{Na}$ accumulation, since there was no significant response for $\mathrm{K}$. Therefore, as the plants without organic matter had higher $\mathrm{Na}$ concentrations, consequently, they had higher $\mathrm{Na} / \mathrm{K}$ ratios.

Maintaining $\mathrm{Na} / \mathrm{K}$ ratio below 0.6 is considered an important criterion in the characterization of plant tolerance to salinity (Cunha et al., 2013; Santos et al., 2016). Thus, despite the linear increase in the $\mathrm{Na} / \mathrm{K}$ ratio due to the level of salinity, plants grown in the presence of organic matter showed values within the adequate range, reducing the impacts of salinity on their metabolism.

\section{Conclusions}

1. Irrigation water salinity and the cultivation environment influence the increase in the leaf concentrations of $\mathrm{Ca}, \mathrm{Mg}$, $\mathrm{Na}, \mathrm{Cl}$ and $\mathrm{Na} / \mathrm{K}$ ratio in noni plants, especially in the open field environment.

2. Organic matter is not much relevant in attenuating the deleterious effects of irrigation water on the concentration of leaf nutrient in noni plants.

3. The maintenance of lower values of $\mathrm{Na} / \mathrm{K}$ ratio in the treatment with organic matter is a positive factor that can attenuate the effects of salt stress on cell metabolism.

\section{ACKNOWLEDGements}

Acknowledgments are due to the Conselho Nacional de Desenvolvimento Científico e Tecnológico (CNPq, Brazil) and Instituto Nacional de Ciência e Tecnologia em Salinidade (INCTSal, Brazil), for financial support.

\section{Literature Cited}

Alvares, C. A.; Stape, J. L.; Sentelhas, P. C.; Gonçalves, J. L. de M.; Sparovek, G. Köppen's climate classification map for Brazil. Meteorologische Zeitschrift, v.22, p.711-728, 2013. https://doi. org/10.1127/0941-2948/2013/0507

Alves, F. A. L.; Silva, S. L. F. da; Lima, J. P. M. S.; Silveira, J. A. G. da. Efeitos do $\mathrm{KCl}$ e $\mathrm{CaCl}_{2}$ na absorção e transporte de $\mathrm{Na}^{+}$em cajueiro exposto ao $\mathrm{NaCl}$. Revista Ciência Agronômica, v.39, p.287-294, 2008.
Cataldo, D. A.; Maroon, M.; Schrader, L. E.; Youngs, V. L. Rapid colorimetric determination of nitrate in plant tissue by nitration of salicylic acid. Communication in Soil Science and Plant Analysis, v.6, p.71-80, 1975. https://doi.org/10.1080/00103627509366547

Cunha, P. C. da; Mendes, B. S. de S.; Oliveira Filho, R. A. de; Camara, T. R.; Willadino, L. G. Crescimento, síntese de solutos orgânicos e equilíbrio iônico de plântulas de pinhão-manso sob estresse salino. Revista Caatinga, v.26, p.46-52, 2013.

Farias, S. G. G. de; Santos, D. R. dos; Freire, A. L. de O.; Silva, R. B. e. Estresse salino no crescimento inicial e nutrição mineral de gliricídia [Gliricidia sepium (Jacq.) Kunth ex Steud] em solução nutritiva. Revista Brasileira de Ciência do Solo, v.33, p.1499-1505, 2009. https://doi.org/10.1590/S0100-06832009000500040

Freire, J. L. de O.; Cavalcante, L. F.; Rebequi, A. M.; Dias, T. J.; Souto, A. G. de L. Necessidade hídrica do maracujazeiro amarelo cultivado sob estresse salino, biofertilização e cobertura do solo. Revista Caatinga, v.24, p.82-91, 2011.

Galati, C. V.; Cecílio Filho, A. B.; Galati, C. V.; Alves, A. U. Crescimento e acúmulo de nutrientes da cultura do quiabeiro. Semina: Ciências Agrárias, v.34, p.191-200, 2013. https://doi.org/10.5433/16790359.2013v34n1p191

Krishnaiah, D.; Bono, A.; Sarbatly, R.; Anisuzzaman, S. M. Antioxidant activity and total phenolic content of an isolated Morinda citrifolia L. methanolic extract from poly-ethersulphone (PES) membrane separator. Journal of King Saud University - Engineering Sciences, v.27, p.63-67, 2013. https://doi.org/10.1016/j.jksues.2013.01.002

Lima, G. S. de; Nobre, R. G.; Gheyi, H. R.; Soares, L. A. dos A.; Pinheiro, F. W. A.; Dias, A. S. Crescimento, teor de sódio, cloro e relação iônica na mamoneira sob estresse salino e adubação nitrogenada. Comunicata Scientiae, v.6, p.212-223, 2015.

Lima, G. S. de; Nobre, R. G.; Gheyi, H. R.; Soares, L. A. dos A.; Silva, A. O. da. Crescimento e componentes de produção da mamoneira sob estresse salino e adubação nitrogenada. Engenharia Agrícola, v.34, p.854-866, 2014. https://doi.org/10.1590/S010069162014000500005

Lucena, C. C. de; Siqueira, D. L. de; Martinez, H. E. P.; Cecon, P. R. Efeito do estresse salino na absorção de nutrientes em mangueira. Revista Brasileira de Fruticultura, v.34, p.297-308, 2012. https://doi.org/10.1590/S0100-29452012000100039

Malavolta, E.; Vitti, G. C.; Oliveira, S. A. Avaliação do estado nutricional das plantas: Princípios e aplicações. 2.ed. Piracicaba: Potafos, 1997. 319p.

Mompié, A. C.; Sanchez, Y. M. P.; Cunhanune, C. L. C.; Lorente, C. de la P.; Aguila, F. C. Evaluation of the antimicrobial activity of extracts from leaves and seeds of Morinda citrifolia L. (noni). Revista Cubana de Plantas Medicinales, v.19, p.374-382, 2014.

Oliveira, L. B. de; Accioly, A. M. A.; Santos, C. L. R. dos; Flores, R. A.; Barbosa, F. S. Características químicas do solo e produção de biomassa de alface adubada com compostos orgânicos. Revista Brasileira de Engenharia Agrícola e Ambiental, v.18, p.157-164, 2014. https://doi.org/10.1590/S1415-43662014000200005

Pandy, V.; Narasingam, M.; Kunasegaran, T.; Murugan, D. D.; Mohamed, Z. Effect of noni (Morinda citrifolia Linn.) fruit and its bioactive principles scopoletin and rutin on rat vas deferens contractility: An ex vivo study. The Scientific World Journal, v.2014, p.1-11, 2014. https://doi.org/10.1155/2014/909586

Rhoades, J. D.; Kandiah, A.; Mashali, A. M. Uso de águas salinas para produção agrícola. Campina Grande: UFPB, 2000. 117p. 
Santos, R. V. dos; Cavalcante, L. F.; Vital, A. de F. M.; Lacerda, C. F. de; Souza, E. R. de; Lima, G. S. de. Interação salinidade-fertilidade do solo. In: Gheyi, H. R.; Dias, N. S. da; Lacerda, C. F. de; Gomes Filho, E. (eds.) Manejo da salinidade na agricultura: Estudos básicos e aplicados. 2.ed. Fortaleza: INCTSal, p.277-293, 2016.

Silva, F. C. da. Manual de análises químicas de solos, plantas e fertilizantes. 2.ed. rev. ampl. Brasília: Embrapa Informação Tecnológica, 2009. 627p

Silva, F. de A. S. e; Azevedo, C. A. V. de. The Assistat software version 7.7 and its use in the analysis of experimental data. African Journal of Agricultural Research, v.11, p.3733-3740, 2016. https://doi. org/10.5897/AJAR2016.11522

Silva, J. J. M.; Cavalcante, L. F.; Nascimento, J. A. M.; Diniz, B. L. M. T.; Souto, A. G. de L. Esterco bovino e potássio na composição mineral de plantas de noni. Ciência Florestal, v.24, p.1021-1030, 2014. https://doi.org/10.5902/1980509816615

Silva, J. M. da; Ferreira, R. S.; Melo, A. S. de; Suassuna, J. F.; Dutra, A. F.; Gomes, J. P. Cultivo do tomateiro em ambiente protegido sob diferentes taxas de reposição da evapotranspiração. Revista Brasileira de Engenharia Agrícola e Ambiental, v.17, p.40-46, 2013. https://doi.org/10.1590/S1415-43662013000100006

Singh, D. R. Morinda citrifolia L. (noni): A review of the scientific validation for its nutritional and therapeutic properties. Journal of Diabetes and Endocrinology, v.3, p.77-91, 2012. https://doi. org/10.5897/JDE10.006

Sousa, A. E. C.; Lacerda, C. F. de; Gheyi, H. R.; Soares, F. A. L.; Uyeda, C. A. Teores de nutrientes foliares e respostas fisiológicas em pinhão manso submetido a estresse salino e adubação fosfatada. Revista Caatinga, v.25, p.144-152, $2012 \mathrm{a}$.
Sousa, G. G. de; Marinho, A. B.; Albuquerque, A. H. P.; Viana, T. V. de A.; Azevedo, B. M. de. Crescimento inicial do milho sob diferentes concentrações de biofertilizante bovino irrigado com águas salinas. Revista Ciência Agronômica, v.43, p.237-245, 2012 b. https://doi.org/10.1590/S1806-66902012000200005

Souto, A. G. de L.; Cavalcante, L. F.; Gheyi, H. R.; Nunes, J. C.; Oliveira, F. I. F.; Oresca, D. Photosynthetic pigments and biomass in noni irrigated with saline waters with and without leaching. Revista Brasileira de Engenharia Agrícola e Ambiental, v.19, p.1035-1041, 2015. https://doi.org/10.1590/1807-1929/agriambi. v19n11p1035-1041

Souto, A. G. de L.; Cavalcante, L. F.; Silva, M. R. M. da; Lima Neto, A. J. de; Diniz, B. L. M. T. Nutritional status and production of noni plants fertilized with manure and potassium. Journal of Soil Science and Plant Nutrition, v.18, p.404-417, 2018. https://doi. org/10.4067/S0718-95162018005001301

Souza, M. C. M. R. de; Lacerda, C. F. de; Amorim, A. V.; Menezes, A. S. Influência da matéria orgânica e do ambiente no crescimento e acúmulo de solutos em Morinda citrifolia submetida à salinidade. Revista Brasileira de Fruticultura, v.36, p.704-712, 2014. https:// doi.org/10.1590/0100-2945-319/13

Souza, M. C. M. R. de; Menezes, A. S.; Costa, R. S. da; Amorim, A. V.; Lacerda, C. F. de; Ribeiro, M. da S. de S. Tolerância à salinidade e qualidade de mudas de noni sob diferentes ambientes e matéria orgânica. Revista Brasileira de Agricultura Irrigada, v.11, p.20522062, 2017. https://doi.org/10.7127/rbai.v11n700682

Taiz, L.; Zeiger, E.; Møller, I. M.; Murphy, A. Fisiologia e desenvolvimento vegetal. 6.ed. Porto Alegre: Artmed, 2017. 858p. 